\title{
Exports of Russian Cereals: Analysis of the Current State and Development Prospects
}

\author{
A.V. Shchutskaya ${ }^{1, *}$ and E.E. Ivanova ${ }^{1}$ \\ *Corresponding author: avs2020@yandex.ru \\ ${ }^{1}$ Samara State University of Economics, Samara, Russia
}

\begin{abstract}
Exports of Russian cereals have been growing for five years. In 2017, exports of Russian cereals came to the second rate in the world, and wheat exports came to the first rate. In near future, Russia intends to increase its export potential and maintain its leadership in the global cereals market. The authors have put forward the hypothesis that increasing exports of Russian cereals are not just the result of a favorable combination of weather, economic and political conditions, but it is an expected result of the development of Russian cereal farming. The purpose of the study is to examine the factors that could increase the volume of exports of Russian cereals, and elaborate perspective ways to develop the export potential to strengthen the Russian position in the world cereals market. Using the methods of theoretical analysis, the authors have revealed the peculiarities of Russian and world market development. Economic and statistical methods of analysis have allowed to determine the trends and the conditioning factors in the cereals market development. The authors have come to the conclusion that increasing exports of cereals are caused by growth in cereals production and changes in the expense side in the Russian cereals balance, as well as an active foreign economic activity to expand cereals supplies, and state exports support. Russia is able to increase the volume of food exports, augmenting not only exports of cereals, but also derivative products, which are characterized by high added value, that is the most promising way to develop the export potential.
\end{abstract}

Keywords: cereals, consumption, exports, market, production, Russia

\section{Introduction}

Cereals production is the leading branch of Russian agriculture. The volume of cereals produced allows not only to meet the domestic cereals needs, but also export cereals to other countries. The recent increase of Russian cereals production and the changes in the world market have allowed Russia to become one of the leaders in the exports of cereals. At the end of 2017, exports of Russian cereals came to the second rate in the world (behind the US), and wheat exports took the first rate, ahead of the EU and the US. Russia's share in the world cereals trade was $12 \%$ [1].

Cereals are the main part of Russian food exports. Due to this fact, the analysis of the current state and perspective ways to develop exports of cereals, that will allow to strengthen Russian positions in the world food market, is the most relevant.

\section{Problem Statement}

In near future, Russia intends to strengthen its position in the global cereals market. The export development, including exports of agricultural products and food, is one of the areas of strategic development in the Russian Federation. To stimulate this development, in 2016 Agricultural Exports Project was included in the State Program of Agricultural Development and Market Regulation of Agricultural Products, Raw Materials and Food in 2013 - 2020. The Project aims to increase the volume of exports of agricultural products to foreign markets up to $\$ 21.4$ billion in 2020 , including $\$ 6.6$ billion of exports of cereals and flour grinding products. However, in 2017 the actual volume of agricultural exports reached $\$ 20.7$ billion [2]. This result was achieved due to a significant increase in exports of cereals: $33.5 \%$ (from $\$ 5.61$ billion to $\$ 7.49$ billion) in comparison with 2016 [3]. In 2017, 43.3 mln tonnes of Russian cereals were exported. It became possible thanks to the record yield of crop-growing products for the last 30 years and favorable weather conditions. However, Russian Grain Union believes that domestic cereals production has a significant export potential and is able to supply 40-50 mln tonnes of cereals to the world market annually [4]. This paper is devoted to the study of the export potential of Russian cereals market.

\section{Research Questions}

To determine the export capabilities of Russian cereals, it is necessary to identify:

- factors that have led to the current volume of exports of cereals,

- directions to develop Russian cereals production in order to maintain leadership in the global cereals market. 


\section{Purpose of the Study}

The purposes of this study are:

- to analyse the factors that have led to growth of Russian exports of cereals,

- to elaborate perspective ways for the development of the export potential of cereals production in Russia.

\section{Research Methods}

To carry out this study, general scientific and special methods and techniques of economic research were used. The methods of theoretical analysis revealed the features of the development in Russian and world cereals markets. With the help of economic and statistical methods of analysis, the trends and the conditioning factors in the cereals market development were determined, and the structure of Russian exports of cereals, including the breeds of cereals and importing countries, was specified. The base of the study was the official statistical data of Russian Federal State Statistics Service (Rosstat), customs statistics of foreign trade of the Russian Federation published by the Federal Customs Service, as well as the scientific papers on Russian and world cereals market.

\section{Findings}

The Russian Federation, which imported cereals in the Soviet period, in recent years has become one of the largest exporters, having leading positions in the world cereals market. Russian exports of cereals have demonstrated strong growth performance for 2015-2017. Thus, according to the official data of Russian Federal State Statistics Service, the volume of exports of cereals was 43.3 mln tonnes in 2017, which is $41 \%$ higher than in 2015 [5]. In comparison with the index of 1990, the exports of cereals increased by 21.7 times. This achievement was due to the change in the cereals balance of the country: an increase in cereals production and a reduction in its domestic consumption (Fig.1).

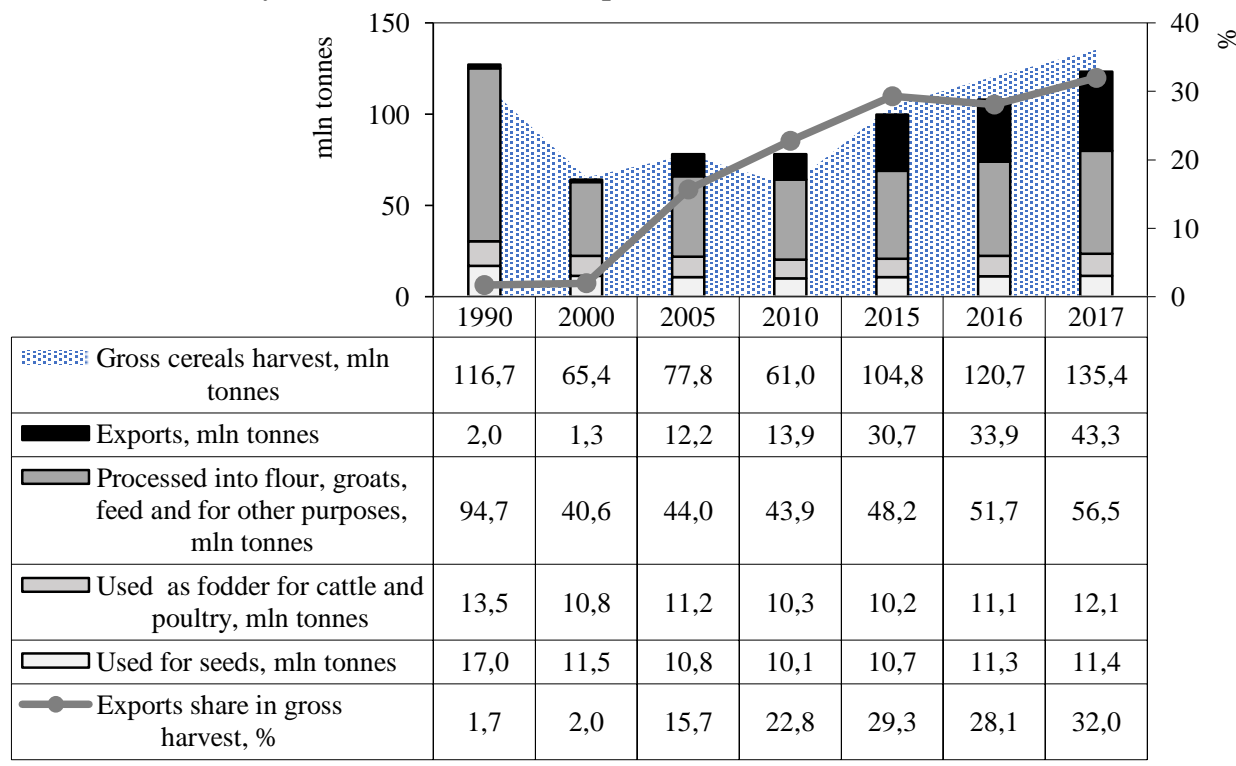

Figure 1. Cereals production and use in the Russian Federation

(Source: compiled by the authors according to Rosstat data [5])

Gross cereals harvest in Russia exceeded 100 mln tonnes in 2014-2017 and had a tendency to increase, reaching 135.4 mln tonnes in 2017. According to the preliminary data of Rosstat, in 2018 the volume of cereals production amounted to $112.9 \mathrm{mln}$ tonnes in weight after processing, which corresponds to the annual average for 2014-2017 [6]. The increase in cereals production in the last 5 years was mainly due to the increase in yield of crop-growing products, the average level of which was 26.1 centners per one hectare harvested. It is $34.5 \%$ higher than in 1990 (19.4 centners per one hectare harvested). In recent years, the cereals industry has been characterized by the highest rates in technical and technological modernization of production and innovation, which ensured growth of production results.

Analyzing the volume of cereals used in the Russian Federation, it is important to note a significant reduction in its industrial processing (by $40.3 \%$ in comparison with the level of 1990). The volume of cereals used for seeds decreased by $32.9 \%$ due to the agricultural acreage decrease by $24.5 \%$, resource economy and the use of precision farming technologies. The cereals volume used as fodder for cattle and poultry decreased by $10.4 \%$ due to the reduced demand for feeding grain and a reduction of animals' number in comparison with the level of 1990. These changes are related to the structural deformation of the Russian farming sector, which can not be considered positive, as it contributed to growth of imports in more expensive animal production [7]. The policy of import substitution, implemented since 2014, 
has modified the cereals balance of the country. Due to the development of domestic animal agriculture and processing industry, domestic cereals consumption gradually began to increase. However, the data in Fig. 1 show that a significant increase in gross harvest has allowed not only to meet the growing domestic demand for cereals, but also significantly increase export supplies. Thanks to the record yield in 2017, the volume of exports of cereals amounted to $43.3 \mathrm{mln}$ tonnes, and the exports share in the gross harvest increased to $32.0 \%$. A significant increase in cereals production led to price drop in Russian cereals market below the export parity. It was the factor that stimulated the overseas supplies. The State supported exporters by subsidizing railway tariffs for the transportation of cereals from the distant regions of the country, as well as developing transport and logistics infrastructure.

The presence of large cereals stock at the end of 2017, heavy yields in 2018, as well as the export results in the first half of 2018 (according to the Federal Customs Service for the first two quarters of 2018, the volume of exports of cereals amounted to 25.3 mln tonnes, which is $63.3 \%$ higher than in 2017) allow to admit the strengthening of Russia's leading position in the global cereals market [8].

According to Russian Federal Customs Service, wheat and meslin (a mixture of wheat and rye) have the largest cereals export share. Their share in Russian cereals exports has increased to $76.4 \%$, and the volume of exports has augmented from $21.23 \mathrm{mln}$ tonnes to $33.06 \mathrm{mln}$ tonnes for 2015-2017 (Table 1).

Table 1. Exports of cereals by cereal breeds and groups of importing countries

\begin{tabular}{|c|c|c|c|c|c|c|c|c|}
\hline \multirow{3}{*}{$\begin{array}{l}\text { Breeds of } \\
\text { cereals }\end{array}$} & \multicolumn{3}{|c|}{2015} & \multicolumn{3}{|c|}{2017} & \multirow{2}{*}{\multicolumn{2}{|c|}{ Structure, \% }} \\
\hline & \multirow{2}{*}{$\begin{array}{l}\text { Total, } \\
\text { mln } \\
\text { tonnes }\end{array}$} & \multicolumn{2}{|c|}{ Including } & \multirow{2}{*}{$\begin{array}{c}\text { Total, } \\
\text { mln } \\
\text { tonnes }\end{array}$} & \multicolumn{2}{|c|}{ Including } & & \\
\hline & & $\begin{array}{l}\text { Foreign } \\
\text { countries }\end{array}$ & $\begin{array}{c}\text { CIS } \\
\text { countries }\end{array}$ & & $\begin{array}{l}\text { Foreign } \\
\text { countries }\end{array}$ & $\begin{array}{c}\text { CIS } \\
\text { countries }\end{array}$ & 2015 & 2017 \\
\hline $\begin{array}{l}\text { Wheat and } \\
\text { meslin }\end{array}$ & 21230.0 & 19709.0 & 1521.0 & 33064.4 & 31497.9 & 1566.5 & 69.2 & 76.4 \\
\hline Rye & 123.4 & 123.3 & 0.1 & 38.4 & 34.4 & 4.1 & 0.4 & 0.1 \\
\hline Barley & 5293.0 & 5229.0 & 64.5 & 4640.6 & 4564.0 & 76.6 & 17.2 & 10.7 \\
\hline Oats & 16.8 & 16.3 & 0.5 & 15.2 & 14.8 & 0.4 & 0.1 & 0.0 \\
\hline Maize & 3698.8 & 3482.0 & 216.8 & 5191.6 & 5047.5 & 144.2 & 12.0 & 12.0 \\
\hline Rice & 179.7 & 64.1 & 115.6 & 183.5 & 133.4 & 50.2 & 0.6 & 0.4 \\
\hline $\begin{array}{l}\text { Grain } \\
\text { sorghum }\end{array}$ & 53.3 & 53.2 & 0.1 & 33.1 & 33.1 & 0.0 & 0.2 & 0.1 \\
\hline $\begin{array}{l}\text { Buckwheat, } \\
\text { millet, and } \\
\text { other cereals }\end{array}$ & 104.8 & 96.4 & 8.4 & 126.2 & 90.6 & 35.6 & 0.3 & 0.3 \\
\hline Total & 30699.8 & 28773.3 & 1927.0 & 43293.2 & 41415.6 & 1877.5 & 100 & 100 \\
\hline
\end{tabular}

Source: compiled by the authors according to the Federal Customs Service data [3].

Maize and barley have a significant share in the structure of exports of cereals. Russia also exports rye, oats, rice, grain sorghum, buckwheat, millet and other cereals, but their total share does not exceed $2 \%$.

Russia mainly exports cereals to foreign countries. In 2017, this market segment was $95.7 \%$ of exports of Russian cereals. The exports of cereals to the CIS countries have decreased by 49.5 thousand tonnes (2.6\%) for 2015-2017, due to a decrease in sales of maize and rice (Table 1). Among the CIS countries, the leading consumers of Russian cereals are Azerbaijan, Georgia and Armenia.

Currently, Russia exports cereals to more than 120 countries and actively expands exports [9]. Traditionally, Egypt and Turkey are the leaders among the countries with a high demand for Russian cereals. In 2015-2017, they bought about $1 / 3$ of the volume of wheat exports. At the same time, wheat exports to Egypt increased by $72.8 \%$ and amounted 7835 thousand tonnes (Fig. 2).

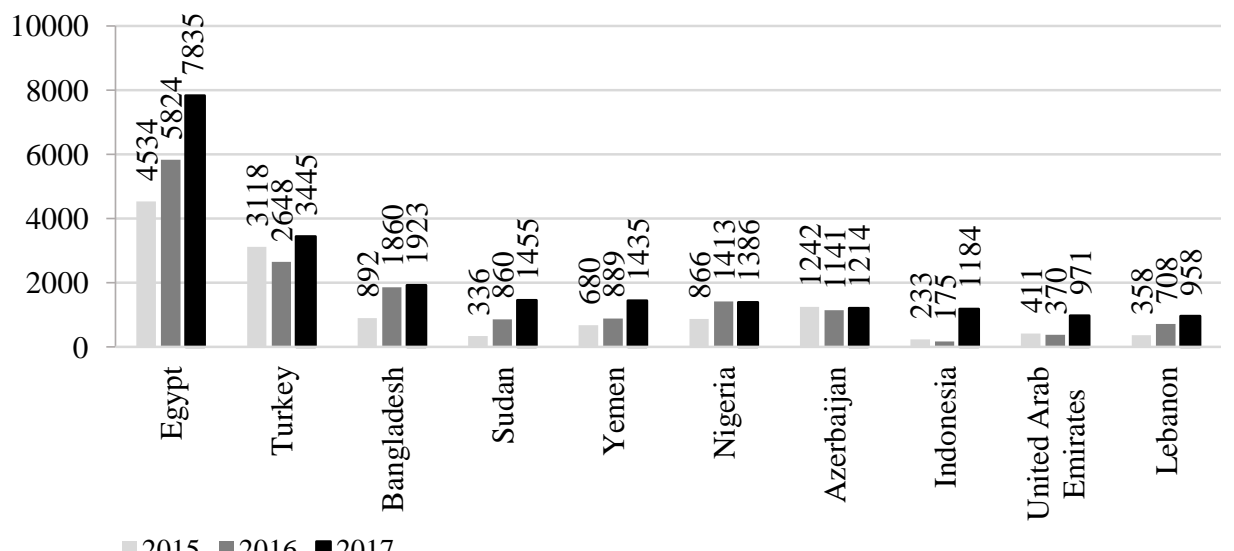

Figure 2.Top 10 importers of Russian wheat, thousand tones (Source: compiled by the authors according to the Federal Customs Service data [3]) 
Wheat exports have increased significantly to Southeast Asia (Indonesia by 5.1 times, Bangladesh by 2.2 times) and to African countries (Sudan by 4.3 times, Nigeria by 1.6 times) for 3 years. These regions are promising for exports of Russian cereals, as there is an increase in the population, and their own land resources are very limited [10].

China is a promising market for Russian cereals. Deterioration in diplomatic relations between China and the United States in 2018 led to a reduction in trade between them. China is reorienting to the purchases of agricultural products in other countries, including Russia. According to the Federal Customs Service in the first half of 2018, 76.96 thousand tonnes of Russian cereals were delivered to China, which is 4.3 times higher than the volume of exports of this product in 2017 [5]. The start of the railway route "New Silk Road" in 2017 also contributed to the expansion of Russian exports to China. Chinese businessmen are interested not only in cereals, but they are ready to buy flour, grits, maize, speedy cooked cereals, as well as confectionery [11].

Cereals production in Russia has a significant growth potential and opportunities to increase exports. According to Russian Grain Union, the country is able to increase cereals production up to 130-160 mln tonnes and exports of cereals up to 40-50 mln tonnes per year in the shortest possible time [6]. The ability of Russia to export 40-50 mln tonnes of cereals is confirmed by studies of a number of scientists (Altukhov [12], Rau [13] and others). Such factors as availability of the world's largest genetic resources of cereals, high access to lands, possibility to expand agricultural acreage, soil and climatic conditions (that allow to obtain relatively cheap environmentally friendly cereals), high yield of crop-growing products and cereals quality (due to the active technical and technological modernization of production), and improvement in a logistics infrastructure contribute to growth of exports of cereals. A significant factor is the territorial proximity of Russia to major markets in Central Asia, North Africa, the Middle East, where population growth is observed [14].

Due to population growth, increase in the world food consumption lays the groundwork for expanding export opportunities. Russia should use these opportunities to strengthen its position in the world cereals market, expand exports not only of cereals, but also derivative products, which are characterized by high added value. The leading Russian experts in cereals farming Altukhov [12], Krylatyh [7], Nechaev [15], Rau [13] consider the production of cereal products after processing with high added value as one of the most promising way to develop the cereals industry. Reorientation from exports of raw materials to end products will increase the country's income and its prestige in the world food market.

\section{Conclusion}

The study has showed that the increase in exports of Russian cereals is caused by the cereals production growth and changes in the expense side in the Russian cereals balance, (a reduction in production consumption and cereals processing). Growth of exports was also facilitated by the favorable price environment in the world cereals market, state exports support, active foreign economic activity to expand cereals supplies. With the current dynamics of cereals production development, Russia is quite capable to provide the annual cereals exports of 40-50 mln tonnes and hold the leading position in the world cereals market. However, the increase of exports should not be at the expense of the development of domestic animal agriculture. Promising areas in Russian exports of cereals are further expansion of products supplies, improving cereals quality, increasing exports of cereals products that are characterized by high added value.

\section{References}

1. A.I. Altukhov, Strategy of the development of the cereal products subcomplex is the basis for the location and specialization of cereal production in the country. Vestnik of Kursk State Agricultural Academy, 5, 146-152 (2018).

2. National Report, Progress and results of the State program implementation in 2017 of the agriculture development and market regulation of agricultural products, raw materials and food in 2013-2020. Retrieved from: http://mcx.ru/upload/iblock/ec8/ec8f3b2c7fa3b4642f76d3fbda07804b.pdf Accessed: 25.10.2018 (2018). [in Rus.].

3. Bulletin, Customs statistics of foreign trade of the Russian Federation in 2017. Retrieved from: http://stat.customs.ru/apex/f?p=201:7:2627582913255609::NO: Accessed: 26.10.2018 (2017). [in Rus.].

4. Concept of Russian cereal market development in the medium term. Retrieved from: http://grun.ru/documents/concepc2017.pdf Accessed: 26.10.2018 (2017). [in Rus.].

5. Key indicators of Russian agriculture in 2017. Retrieved from: http://www.gks.ru/wps/wcm/connect/rosstat_main/rosstat/ru/statistics/publications/catalog/doc_1140096652250 Accessed: 25.10 .2018 (2018). [in Rus.].

6. Agricultural acreage, gross harvest and yield of crop-growing products in the Russian Federation in 2018 (preliminary data). Retrieved from: http://www.gks.ru/wps/wcm/connect/rosstat_main/rosstat/ru/statistics/publications/catalog/doc_1265196018516 Accessed: 26.11.2018 (2018). [in Rus.].

7. E.N. Krylatyh, T.N. Belova, Russian cereal exports in the context of the regional economic policy. Economy of the Region, 3, 778-790. DOI: 10.17059/2018-3-7 (2018). 
8. Bulletin, Customs statistics of foreign trade of the Russian Federation in the second quarter in 2018. Retrieved from: http://stat.customs.ru/apex/f?p=201:7:2627582913255609::NO: Accessed: 26.10.2018 (2018). [in Rus.].

9. G.G. Karpenko, A.A. Antontsev, The main trends in the development of production and the cereal market in Russia and in the world. Public Administration. Electronic Bulletin, 69, 56-79 (2018).

10. V.V. Rau, Russian food exports: trends, opportunities, and priorities. Studies on Russian Economic Development, 28(4), 431-436. DOI: 10.1134/S107570071704013X (2017).

11. R.V. Nekrasov, Development of export potential of grain economy in Samara region. Vestnik of Samara State University of Economics, 12(158), 43-49 (2017).

12. A.I. Altukhov, Russian cereal exports: problems and solutions. Nikonovskie Chteniya, 22, 134-136 (2017).

13. V.V. Rau, On the development strategy for the grain sector. Studies on Russian Economic Development, 27(1), 4553. DOI: 10.1134/S1075700716010111 (2016).

14. V.P. Zaikin, I.V. Ryabov, Study of the resources balance and cereal use. Vestnik of Nizhny Novgorod State University of Engineering and Economics, 9(76), 88-102 (2017).

15. V.I. Nechaev, P.V. Mikhailushkin, T.N. Slepneva, New approaches to deep cereal processing on the basis of the interstate cluster formation (Russia - Kazakhstan). Economy of Agricultural and Processing Enterprises, 9, 52-55 (2017). 